\title{
Quality of High-Tech E-learning in Saudi Universities
}

\author{
Abdullah Saleh Alshetwi \\ Beihang University, Beijing, 100191 (China) \\ shetwi.a@hotmail.com
}

\begin{abstract}
This paper deals with adoption of information and communication technology (ICT) in Saudi universities. and development of ICT to beneficial to Saudi societies. The rapid growth in wireless communication technologies and high-speed network applications to the internet, provide better facilities to the prevalence of educational programs and practices, notably e-learning remote, and the emergence of virtual schools and universities. In this way, many social problems in education, such as growing numbers of learners, and the geographical imbalance of educational institutions, and inability of existing institutions to meet the needs of development, can be fundamentally solved, and this e-learning in remote areas can further supply abundance of information, and transfer roles of teacher and students in continuing education. It is expected that in the future, the new technologies used in Saudi universities will not only increase intellectual productivity but also accomplish a qualitative change in the nature of learning. The e-learning in Saudi Arabia universities requires people and relevant technologies actively to tackle obstacles in order to make e-learning accessible and continually generates solution to improve education, especially in university level. Such understanding and the awareness of importance of accessible e-learning are highly crucial and should be accompanied by developing appropriate and enforceable policies aimed at improvement of legacy of distance learning among potential students.
\end{abstract}

Key words: ICT, Distance learning, Virtual classroom

\section{Introduction}

Many universities have realized the important function of information and communication technology (ICT) as it can improve delivery of information / professional knowledge and services to potential students. The Web phenomenon has changed the ways that many of the famous academic institutions work and communicate. E-learning helps solving the problem of knowledge explosion and the growing demand for education, expands opportunities for acceptance in education which can also be trained and educated staff without leaving their jobs, and helps break the psychological barriers between the teacher and the learner, also the satisfaction of the needs, characteristics of the learner and increase the return on investment by reducing the cost of education.

Due to a broad global attention given to e-Learning, various reports and studies had been conducted by academe, different organizations as well as the government of various nations (Rosenberg, 2001). The Saudi Ministry of Higher Education is among those educational organizations that proposed the use of e-learning in Saudi Arabia. The Saudi Ministry of Higher Education initiates the need of integrating Information and Communication Technology in various universities in Saudi Arabia. The Saudi Gazette (2008) by Madar Research reported that "the Saudi Arabian E-learning industry is projected to reach USD 125 million in 2008 and is set to grow at a compound annual rate of 33 per cent over the next five 
years". The increased projection shows vital focus on the advantages of e-Learning in Saudi Arabia's modern education.

\section{Research Objectives}

This research has following objectives:

- To present a better understanding of the application of different ICT services and e-learning in Saudi institutions. The main issue here is to show how distance learning methods and technology can be used to improve higher education opportunities.

- To study thoroughly the current situations of implementing e-learning in Saudi Higher Education. In this regard, challenges that affect integrating technology into the teaching and learning process are to be assessed.

- To identify factors that lead to adopt e-learning successfully in Saudi universities. That is to help Saudi educational institutes that intend to apply the e-learning system so that they would be able to recognize different ways to enhance the acceptance of the overall e-learning system.

\section{Development and Unique nature of E-Learning}

The paper is especially focused upon adoption of e-learning in Saudi universities. The study is to focus on the way of importance of current situation and future teaching methodologies and strategies at in Saudi universities. If we look at education from the perspective of a computer, there are three types of education found over time until the present day, traditional education, education using the computer and education using the Internet. Therefore, there are basically three stages of the development of modern educational system, namely:

- Traditional education

- Education using a computer

- Education using the Internet (e-learning)

E-learning helps solving the problem of knowledge explosion and the growing demand for education, expands opportunities for acceptance in education which can also be used for training and educating business and professional staff without leaving their jobs, and helps break the psychological barriers between teachers and learners, thus satisfying social needs, especially fitting for natures of the learners and increase overall return on investment by reducing cost of education.

E-learning has been used in education as early as 1950's. At that time E-learning was referred to as distance teaching (Clark, 2000). The term E-learning refers to the learning methods which use electronic channels to deliver the instructional content. Moreover, E-learning is also referred to as web-based learning; technology based learning; online learning; networked learning and so on (Trombley \& Lee, 2002; Wilson, 2001; Gotschall, 2000).

E-Learning is not just an "added value" to facilitate and accelerate traditional education. It is an evolving environment integrated with various elements of the educational process, in order to be enriched from within. E-Learning does not only provide massive information "vessels", but also stimulates in the learning mechanisms of information acquisition, its processing, and sharing with others in its construction, and conversion into interactive positive information. Based on the main definition, e-learning is kind of education system 
using communication mechanisms computer based networks and multimedia voice, as well as accumulated information sets such as photos, graphics, libraries, and necessary electronic means and software based search engines, as well as internet portals, whether remotely or in the classroom. It is important to emphasize the use of technologies of all kinds to deliver information to the learner with shortest time and less cost.

Distance Learning is defined as not just bringing time and space closer but also an interactive presence, allowing all parties to perform all educational activities at any time from any place. On the other hand, distance Learning is not "the easiest way" to get a certificate without attending. It is an effective method to raise the quality of education, because it allows both teacher and learner to choose the most suitable time and space for them to meet and interact. In this research e-learning is the master method studied because it is convenient, relevant, immediate, affordable, eliminates lost opportunity expenses.

\section{E-Learning in Saudi Arabia}

\subsection{The National Policy of E-learning}

The Saudi Arabia important step in order to activate the role of technology in Education, especially in higher education, and in 2007, the country implemented a nationwide National Plan for promotion of information technology, which pushed adoption of e-learning and distance learning in higher education and the establishment of the Centre National to provide technical support, with necessary tools for development of digital learning content. Such implementation of the National Centre for e-learning and distance education was the first of its kind to spread application of e-learning and distance education so widely in educational institutions and universities, enabling them to adopt the latest facilities in the field of e-learning and education distance, which in turn developed e-learning in Saudi universities through agreements with universities and thus provided scientific and technical support for universities.

Heading by the Ministry of Higher Education in the country to recognize the distance education and e-learning both at local universities or universities in the country level, the action pushed forward important steps toward next generation of education. At very first, it was primarily an introduction of e-learning distance in all Saudi universities to facilitate the students with more educational opportunities. Further steps will provide citizens in the country to share opportunity of higher education services. Indeed, e-learning and distance education can get all students to seat in the universities through distance education with much reduced costs of the parents and the students involved, as well as reduce congestions on the streets morning and evening, resulted also in reduction of self-education class.

Regarding to universities and colleges in the Kingdom adopting e-learning methods as part of their school curriculum, it is expected that the growth of such e-learning market in the Kingdom can be as high as by 33\% per annum over the next five years, much higher than previous forecast value (\$125 million) in 2008 .

\subsection{Case Study of Saudi University}

It is worth mentioning that the University: King Abdul Aziz University in Jeddah, Al-Imam Muhammad bin Saud Islamic University in Riyadh, was a world leader in application of the technologies to distance education. At the University of King Abdul Aziz the e-learning was launched as the Deanship of Distance Learning in 2004, and the relevant classes and teaching courses included several specialties, such as Arabic, English,

Abdullah Saleh Alshetwi, academic title: Marketing management, Department: Economics \& Management, Beihang University. Correspondence concerning this article should be addressed to Abdullah Saleh Alshetwi, Address: E-mail: Shetwi.a@hotmail.com. 
psychology, business administration, public administration. And home to the headquarters of the University "Saudi Association for Distance Education" is supporting all activities related to the development of techniques and systems of distance education.

At the University of Imam Muhammad bin Saud Islamic University e-learning was opened as the Deanship of Distance Learning in 2007, and the studies included other courses, such as law, advocacy, business management, and economics. Furthermore, it also developed a study to introduce more disciplines, such as Arabic. The requirements for admission, on the whole, are easy and affordable, and require the Deanship of Distance Learning, Imam University, passing the applicants for the study of "training course" as a prerequisite for admission to the undergraduate program. The reasons for the requirement to pass this session (sixteen weeks) are actually aimed at calling qualify students for university studies over knowledge of methods and systems of study.

\subsection{E-learning Systems in the Universities}

King Abdul Aziz University in Jeddah, the representative of the Deanship of Distance Learning management systems provide the latest e-learning distance LMS Learning Management System. The functions of this system is to provide scientific material to student via internet, and to provide lectures in remote classroom, accompanied with e-discussion distance between teachers and students, and with implementation of forum e-discussion among students. The system also includes distribution of duties and solution collections, providing tests remotely, either for experimentation or to test the actual results after the availability of guarantees. The integrity of the process, as well as of the students can be checked or examined through presentations on research projects by students and active presence of professors or teachers inserted through article reading by the students.

This system depends on through organization (by universities). Each student is given an account to be able to access his/her own page like LMS (Learning Management System) system. Furthermore, a student receives all the lectures through the web site of the university and contacts his/her Professor. Even in the case of not being able to attend the e-lecture on time for any reason, student can download it from the university webpage. Many universities adopted this model of the study, such as in the University of King Abdul-Aziz in Jeddah, Al-Imam Muhammad bin Saud Islamic University and Taiba University.

The King Abdul-Aziz University is based on two electronic distance education: EMES and Centra.

Following is detailed framework of EMES.

An integrated computer system that manages the educational process aims to facilitate the interaction between student and faculty member; the studies have shown that the best model for distance education can be indicated by an example of so-called Blended Solution with various techniques. This model requires the provision of systems for the management of distance.

E-learning management system is an integrated computer system to serve the educational process from a distance, where the system aims to facilitate the process of interaction between student and professor.

\subsubsection{System Features of EMES}

- Scalability.

- Easy to use. 
- supported the Arabic language.

- Needless to methods of student assessment.

- Rich in ways that connect students with teachers.

- Quality of instructional design and employment of modern technology and use it as an educational tool.

- Developing self-learning among students.

- Easy to follow and good management of the educational process.

\subsubsection{How to access EMES}

From a web browser if entering relevant address, http://emes.kau.edu.sa will appear,

The login screens of the system is shown in this screenshot (Figure 1) and represent main interface for e-learning program EMES.

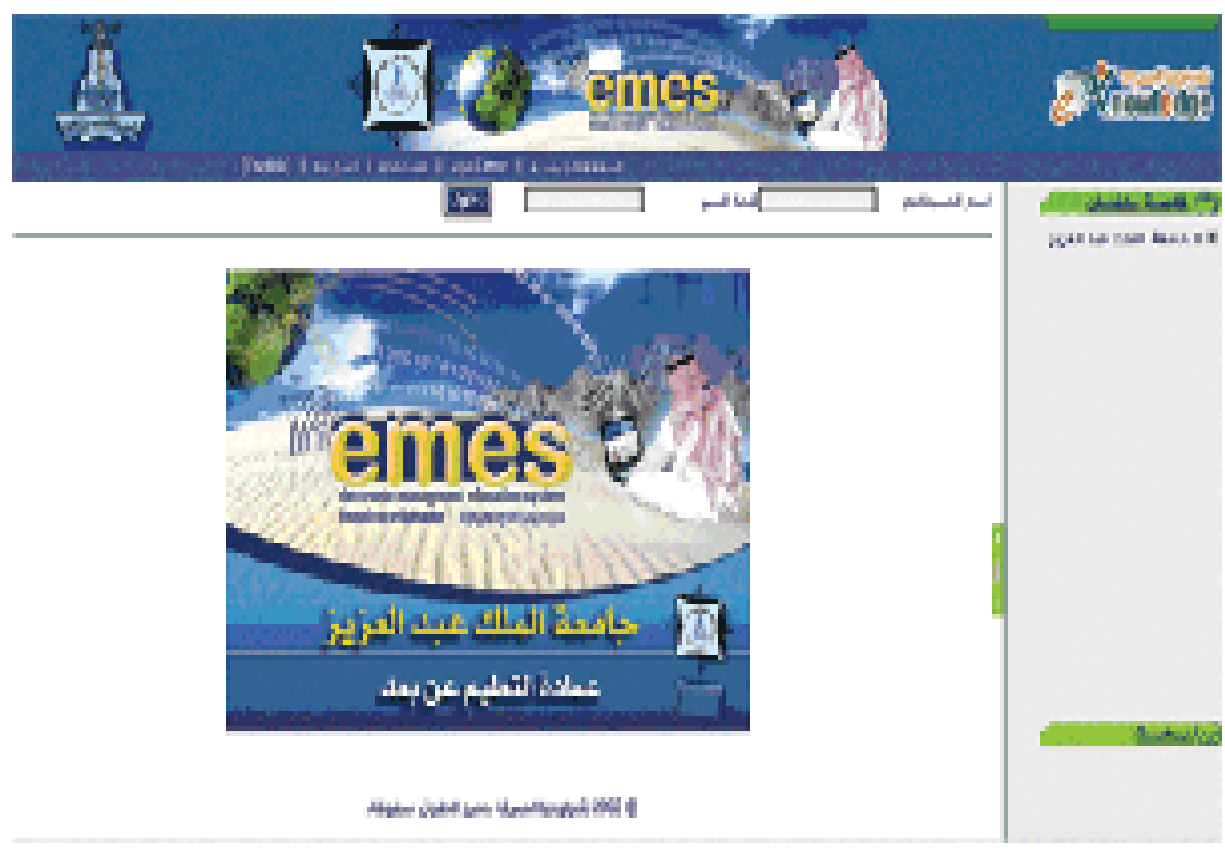

Figure 1. Screenshot of EMES Source: kau

\subsection{Evaluation of the Reality of E-learning in Saudi Universities}

The Kingdom desperately needs to provide higher education opportunities for thousands of students, and the need to meet growing demand for university education, relevant institutions under Ministry of Higher Education were established two years ago, including "National Centre for e-learning and distance education", so as to support the efforts of Saudi universities in this type of education. Actually, universities initiated in this area many relevant programs, for example, King Saud and King Fahd University of Petroleum and Minerals, King Faisal, provided for students with some basic courses on the web, King Abdul-Aziz, mother of the villages, and King Khalid, centers for distance education and e-learning provides some lectures on the web site.

Abdullah Saleh Alshetwi, academic title: Marketing management, Department: Economics \& Management, Beihang University. Correspondence concerning this article should be addressed to Abdullah Saleh Alshetwi, Address: E-mail: Shetwi.a@hotmail.com. 


\subsection{The Future and Challenge of E-learning}

However, at this point, it should be noted that it is still long way to go for Saudi Arabia to develop modern e-learning system in the areas, by improving and continuing use of computers in education, both as for teaching material within the general education curriculum or in connection with its use in the management of the educational process and for a specialized software that manages the process of education both in the management of students and teachers and in the tests and as an educational tool, the Kingdom of Saudi Arabia has adopted an ambitious national project to use computers in the field of education and called it "the draft Abdullah bin Abdulaziz of Saudi students and children of the Computer.

\section{Conclusion \& Recommendations}

It has been found that e-learning and distance education in all Saudi universities are facilitating more educational opportunities for citizens to get higher education. It is worth mentioning that e-learning and distance education will get all students to seats in the universities quantitatively and qualitatively.

Yet it showed, with no doubt, that some universities' websites in Saudi Arabia still need considerable efforts to become accessible websites at all. This, in turns, will encourage government to support this type of study and make higher education more attainable, more convenient, and more affordable.

Finally, the successful implementation of e-learning website accessibility would enable many students to get involved directly in the community which brings better future for all.

The author believes that it is important to recommend e-learning to enrich the current pedagogical tendencies in the country. However, the adoption of such type of education in Saudi universities has many challenges; following are few of them with suggested recommendations:

Problem1: Mis-recognition in e-learning study at universities leads to failure to adopt this type of study.

Solution1: Ministry of Higher Education should recognize the importance on distance education and e-learning in both local universities and universities recognized by the Ministry of Higher Education.

Problem2: Difficulties in finding a chance to get a higher education in the local universities, because of the larger numbers of students already in each university.

Solution2: e-learning distance in all Saudi universities can facilitate more educational opportunities for citizens to get higher education.

Problem3: The reserved seats in the universities can only provide a small chance to other students to study.

Solution3: It is worth mentioning that e-learning and distance education will get all students to seats in the universities through distance education.

Problem4: It has experienced that many of the obstacles faced by the adoption and application of e-learning in Saudi universities.

Solution4: Adoption by government effort is needed to support this type of study.

\section{References}

[1] C. Dearnley, "Student Support in Open Learning: Sustaining the processes", International Review of Research in Open and Distance Learning, vol. 4, no. 1, (2003).

[2] L. P. Dringus, "From both sides now : On being an Online Learner and Online Instructor", E-Learn Magazine, 
Association of Computing Machinery, [online assessed (2003) April 25.

[3] C. Evans and J. P. Fan, "Lifelong Learning through the Virtual University", Campus-Wide Information Systems, vol. 19, no. 4, (2002), pp. 127-134.

[4] M. Mahmood Abbad, "Looking under the Bonnet: Factors Affecting Student Adoption of E-Learning Systems in Jordan", International Review of Research in Open and Distance Learning, vol. 10, no. 2, (2009).

[5] I. T. Bastiaens, "THE PILLARS and Barriers of E-LEARNING in Syria", (Eds.), Proceedings of World Conference on E-Learning in Corporate, Government, Healthcare, and Higher Education, Chesapeake, VA: AACE, (2009), pp. 71-88.

[6] A. A. Musawi, "Issues and Prospects of E-Learning in Oman", P. Barker \& S. Rebelsky (Eds.), Proceedings of World Conference on Educational Multimedia, Hypermedia and Telecommunications (2002), pp. 17-18.

[7] S. Al-Fadhli and A. Khalfan, "Developing critical thinking in e-learning environment: Kuwait University as a case study", Computer \& Information Systems Department, College of Business Studies, Kuwait, (2009).

Abdullah Saleh Alshetwi, academic title: Marketing management , Department: Economics \& Management, Beihang University. Correspondence concerning this article should be addressed to Abdullah Saleh Alshetwi, Address: E-mail: Shetwi.a@hotmail.com. 
International Journal of $u-$ and e-Service, Science and Technology Vol. 7, No. 6 (2014) 